\title{
THE NATIONAL ENERGY BOARD AS INTERMEDIARY Between the Crown, Aboriginal PeOples, ANd INDUSTRy
}

\author{
MORRIS POPOWICH ${ }^{*}$
}

Recen Supreme Court of Canada decisions have forced the National Enengy Board to reconsider its responsibilities with respect to Aboriginal peoples. This has impacted the Board's ability to clearly. arficulate its policies and procedures. specifically in the area of consultation with Aboriginal peoples, as the legal standard for consultation seems to change from year to year and stakeholders on all sides of the regulatory process press the Board to inferpret these legal requirements in a way that suits their interests best.

This article outlines challenges facing the Board with respect to consultation with First Nations and identifies strategies through which it has attempted to address them. Specifically, it describes the Boord's policies on consulhation and its administrative response to the MacKenzie Valley pipeline regulatory' review. The article assesses the viahiling of these strategies in light of the most recent case law and also in light of challenges the Board is likely to face in the near future.
Les récentes décisions de la Cour supreme du Canada ont force l'Office national de l'ënergie d̀ recontiderer ses responsabilices à l'égand des penples anurchtones. ce qui a eu un effet sur la capacité de l'OJfice à clairement exprimer ses politiques at procidures. specialemen dans le domaine de la consultation avec les petuples antochtones, étant domé que la norme juridique de consultation semble changer d'anneie en annee. et que les intervenants de tous les cotes du processus réglementaire poussem / Office c̀ interpréter ces exigences juridiques de manière à convenir à leurs meilleurs intérèts.

Cel article enonce les defis auquel / OPfice fait face en ce qui concerne la consultation avec les Premieres nations, ef idemifie les stratigies essanje's pour aborder ces défis. Tout particulicrement. Iarticle décrit les politiques de l'Office sur la consulfation et la réponse administrative à l'examen réglementaire du pipeline de la vallee du MacKenzie. L 'article évalue la viabilité de ces strategies à la lumière de la plus recente jurisprudence et des defis atuqual toffice devra faire face très bientòt.

\section{TABLE OF CONTENTS}

I. INTRODUCTION ................................. 837

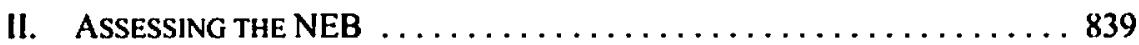

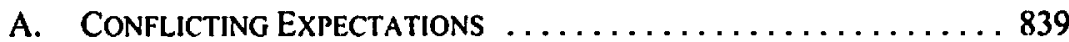

B. Creation of Statute, Creature of Context $\ldots \ldots \ldots \ldots .843$

C. THE NORTHERN PIPELINE AND THE NEB $\ldots \ldots \ldots \ldots \ldots \ldots \ldots .648$

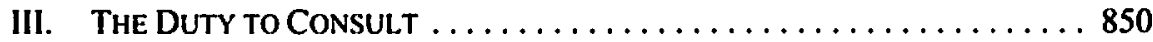

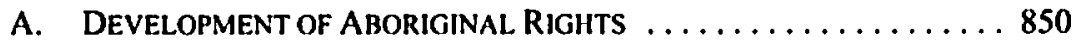

B. HONOUR OF THE CROWN .................... 851

C. SCOPE OF THE DUTY $\ldots \ldots \ldots \ldots \ldots \ldots \ldots \ldots \ldots \ldots$

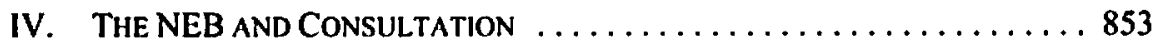

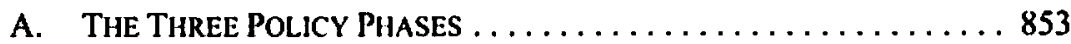

B. FUTURE DEVELOPMENTS $\ldots \ldots \ldots \ldots \ldots \ldots \ldots \ldots \ldots \ldots \ldots, \ldots \ldots \ldots$

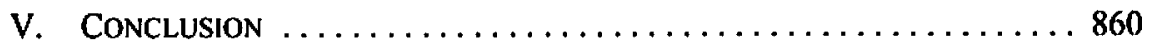

\section{INTRODUCTION}

In recent years, the National Energy Board (NEB or Board) has faced a number of significant regulatory challenges. As rising energy prices have led to an influx of investment 
in Canada, the regulatory workload for the NEB has increased significantly.' This has occurred while the ground beneath the NEB has, so to speak, shifted dramatically with respect to certain stakeholders in the regulatory process.

In particular, recent Supreme Court of Canada decisions have forced the NEB to reconsider its responsibilities with respect to Aboriginal peoples. This jurisprudence has impacted the Board's ability to clearly articulate its policies and procedures, specifically in the area of consultation with Aboriginal peoples, as the legal standard for consultation seems to change from year to year and stakeholders on all sides of the regulatory process press the Board to interpret these legal requirements in a way that best suits their interests. Moreover, as First Nations continue to aggressively litigate their rights in the courts, the ground continues to shift for the Board. In August of 2005, the Board revoked a Memorandum of Guidance (MOG) on consultation with Aboriginal peoples that it had previously issued in 2002.

In the following analysis I will outline the challenges facing the Board with respect to consultation and then identily strategies through which it has attempted to address them. Specilically, I will describe the Board's policies on consultation and its administrative response to the MOG and the MacKenzie Valley pipeline regulatory review. I will then assess the viability of these strategies in light of recent case law, and also in light of challenges the Board is likely to face with respect to consultation.

As the analysis will demonstrate, the Board has limited its contact with First Nations through a policy of delegating the responsibility for consultation to project proponents. Further, the Supreme Court has ruled that the Board's quasi-judicial role in the regulatory process means that it has a different relationship with Aboriginal people than that of the Crown. Finally, the Board is also limited by its close relationship with government as well as by its own institutional and regulatory objectives.

It will be shown that these limitations have led to an unsatisfactory state of affairs for both private industry and Aboriginal peoples. On the one hand, they leave some First Nations with a diminished capacity to effectively advocate their interests within the consultative scheme the Board has devised. Il is also unsatisfactory for private industry if First Nations seek relief through costly and time-consuming court proceedings outside the established Board process. In the past it may have been true that $A$ boriginal peoples had little ability to interrupt major energy projects. However, as they become more sophisticated in their approach to matters regulated by the Board, and as courts continue to expand the consultative responsibility of the Crown, there are new legal avenues through which disaffected groups can interrupt applications to the NEB.

NEB. 2006 Annual Kepon to Parliament. online: NFB <www.nch-onc.ge.ca//'ublications/Annual Reports/2006/AnnualReport2006 e.pdl'?.

: NEB, Letler from the NE:B to Companies subject to the Jurisidiction of the National Encrgy Board. Federal and Provincial Govemment Departments and Agencies and Representatives of Aboriginal Peoples, "Implications of Supreme Court of Canada Decisions on the National Energy Board's Memorandum of Guidance on Consultation with Aboriginal People" (3 August 2005), online: NEB <www.neb.ge.ca/ll-eng//ivelink.exe/fetch/2000/90463/231144/375594/A0R5U7_-_Letter.pdf"? nodeid $=37554$ \& \& vernum $=0$. 


\section{Assessing THE NEB}

\section{A. Conflicting Expectations}

Two recent Supreme Court of Canada decisions confirmed the Crown's duty to consult with Aboriginal peoples and expanded it to apply to situations "when the Crown has knowledge, real or constructive, of the potential existence of the Aboriginal right or title and contemplates conduct that might adversely affect it." This duty was then applied in Mikise'w' Cree First Nation v. Canada (Minister of Canadian Heritage) $)^{4}$ to include situations where the Aboriginal peoples have a treaty with the Crown. Together, the three Supreme Court cases of Haida Nation, Taku River, and Mikisew Cree have been termed the "consultation trilogy." The December 2005 decision in Hupacasath First Nation v. British Columbia (Minister of Forests) ${ }^{5}$ further extends the duty to consult to government decisions regarding land held in fee simple.

It is not yet known how these decisions will impact the NEB given that the previous leading case in this area, Quebec (A.G.) v. Canada (National Energy Board). dealt only with the question of the Board's fiduciary duty to Aboriginal peoples. In that decision the Supreme Court held that the NEB does not have a fiduciary duty toward Aboriginal peoples because it is a quasi-judicial body. ${ }^{7}$ Rather, the Court emphasized that "the Board must exercise its decision-making function, including the interpretation and application of its governing legislation, in accordance with the dictates of the Constitution, including s. 35(1) of the Constitution Act, 1982." "The Court went on to reason that even if it had decided that the Board had a fiduciary duty to the Cree, which it does not, that the Board had satisficd this duty because the Cree were given a fair opportunity to participate fully in the Board's hearing."

There are two reasons to believe that the standard set out in Hydro-Quebec is no longer sufficient and that the courts may be willing to revisit the role of the NEB in the aftermath of Haida Nation. First, Haida Nation recasts the duty to consult as a duty existing prior to any fiduciary obligation between Aboriginal peoples and the Crown. Thus, the Board may have a duty to consult with Aboriginal peoples even if it does not have a fiduciary duty. Second, the consultation trilogy sets out the standard for measuring whether consultation has

I Ilaida Nation v. British Columbia (Minister of Forests), 2004 SCC 73, [2004] 3 S.C.R. 51 I al para. 35 [Haida Nation]; Taku River Thingit First Nation v. British Columbia (Project Assexsment Director), 2004 SCC 74, [2004] 3 S.C.R. 550 [Taku River].

- 2005 SCC 69, [2005] 3 S.C.R. 388 [Wikisen Crec]. 2005 BCSC 1712. 51 B.C.I.R. (4th) 133 [Hupacasath First Nution].

[1994] I S.C.R. 159 [Mlydro-Quebec]. This decision arose as an appeal of a decision of the NEB regarding the issuance of licenses to export power to Vermont and New York. The decision was appealed to the Federal Court of Appeal and then to the Supreme Coun of Canada on a number of grounds, one of which involved the Aboriginal rights of the James Bay Cree in Nortlueru Quchec. The Cree argued that the NEB owed them a liduciary duty in the exereise of its decision-making power, and that the requirements of this duty were not fulfilled.

Ibial. at para. 37.

* Ibid. at para. 40. See Constitnion Act, 1982, being Schedule B to the Canada Acf /982 (U.K.), 1982 , c. 11 .

Ibid. at para. 44. 
been adequate, and it is not clear that the NEB's actions in Hydro-Quebec were sufficient to meet this standard.

A determination that the NEB has a duty to consult with Aboriginal peoples hinges on a finding that it is a part of the Crown. The issue is of fundamental importance to the subsequent analysis. If the NEB is part of the Crown then it has a duty to consult with Aboriginal people. If the NEB is not part of the Crown then it is improbable that it would have a legal duty to consult with Aboriginal people.

This is an aspect of this newly emerging area of law that has yet to be explained in the scholarly literature. However, as Michelle Maniago noted in a recent unpublished study of the topic, the central question is that of the ambit of the Crown. "While Maniago considered this question with respect to administrative agencies generally, she also looked specifically at the NEB and concluded that it should not properly be considered as part of the Crown." Rather, her view is that the NEB is an agent of the Crown rather than part of the Crown itself.

Despite the significance of this topic for administrative agencies, Maniago found that court decisions on the duty to consult have often failed to consider whether these agencies are part of the Crown. The result is that the relationship of the NEB to the Crown in the context of the duty to consult has yet to be determined.

In considering how a court might decide the issue, however, it is possible to look at existing decisions with respect to other similar administrative agencies.

In an appeal from a decision of the Alberta Energy and Utilitics Board (AEUB), which has similar statutory responsibilities to the NEB, ${ }^{12}$ the Alberta Court of Appeal ruled that the AEUB is not an "emanation of the crown," and therefore has no duty to consult. ${ }^{13}$ This aspect of the decision was not an issue on appeal and it was admitted by the Court that there was not enough of a factual record to make a definitive determination about the responsibility of the Crown. For these reasons, the Court's finding with respect to the AEUB and its connection to the Crown is possibly in obiter, and might not be considered dispositive of the issue in future legal disputes. Nevertheless, the Court's commentary in this case on the status of the AEUB identifies a possible resolution to any future legal dispute about Aboriginal consultation involving the NEB.

A decision of the British Columbia Supreme Court, Saulteau First Nations v. British Columbia (Oil \& Gas Commission) ${ }^{14}$ ruled that the British Columbia Oil and Gas Commission (OGC) is part of the Crown and has both a fiduciary duty and a duty to consult with Aboriginal peoples. The Court argued that the OCG and the NEB (the latter of which does not have a fiduciary duty) can be distinguished on the basis that the OCG does not have

10 Michelle Maniago, "A Matter of t lats: Understanding the Ambit of the Cruwn and the Duty to Consult (2007) [unpublished paper completed for Intensive Program in Aboriginal Lands, Resourees and Govemment, Osgoode [lall Law School].

"Ibid. at 21.

1: $\quad$ bid. See Aberta Energy and Urilities Board Acr, R.S.A. 2000, c. A-17.

"Dene Tha 'First Nation v. Alberta (Energy and Uititics Board), 2005 ABCA 68, 363 A.R. 234. leave to appeal to S.C.C. refused. [2005] S.C.C.A. No. 176 (QL.).

2004 BCSC 92, 11 Admin. L.R. (4th) 210 [Saulteau]. 
an adjudicative function with formal hearings or a formal record, and also that the members of the OCG do not have security of tenure. Hence, an imposition of a fiduciary duty would not interfere with the OCG's responsibilities since it does not have a quasi-judicial function.

While the decision in Sauleau follows Hydro-Quebec in finding that a Board's quasijudicial function prevents it from having a fiduciary duty to Aboriginal peoples, there still remains the possibility that a future court ruling will impose a duty to consult on the NEB that is also consistent with $H_{y}$ dro-Quebec. As noted above, the first step requires a decision that the NEB is part of the Crown. Second, such a finding would likely be based on the Supreme Court's argument from the consultation trilogy that the duty to consult is not contingent on the existence of a fiduciary relationship between the First Nation in question and the NEB. Rather, it would be argued that the relatively new concept of the honour of the Crown imposes a duty to consult regardless of whether there is a fiduciary relationship.

Such a finding would also likely have to explain that the NEB's quasi-judicial function would not be impaired by an imposition of a duty to consult as this is an important basis for the Court's reasoning in $\mathrm{Hy}_{\mathrm{y}}$ dro-Quehec that a fiduciary duty cannot apply to the Board. ${ }^{15}$ The Supreme Court may have already spoken to this type of situation in Haida Natiom. In that decision, McLachlin C.J.C. stated that in order to meet its duty to consult "[t]he government may wish to adopt ... administrative regimes with impartial decision-makers in complex or difficult cases."16 Rather than restricting quasi-judicial decision makers such as the NEB, McLachlin C.J.C. seems to be encouraging government to make them a part of the consultation process. However, it is not clear from this statement whether she intended that impartial decision-makers, such as the NEB, carry out consultation themselves or merely assess the adequacy of consultation carried out by other participants. Given the reasoning in Hydro-Quebec, it seems correct to say that if the Board's ability to fulfill its quasi-judicial functions is impaired then it cannot carry out consultation. However, regardless of its ability to carry out consultation, it would still be fully capable of assessing the adequacy of consultation carried out by other participants.

That being said, it is not immediately obvious that every situation requiring consultation would interfere with the quasi-judicial function of the Board. Rather, it would depend on what type of consultation is required in a given circumstance. In Haida Nation, McLachlin C.J.C. discussed the concept of a spectrum for understanding the appropriate standard of consultation:

Al one end of the spectrum lie cases where the claim to title is weak, the Aboriginal right limited. or the potential for infringement minor. In such cases, the only duty on the Crown may be to give notice, disclose information, and discuss any issues raised in response to the notice....

At the other end of the spectrum lic cases where a strong prima facie case for the claim is established, the right and polential infringenent is of high signilicance to the $A$ boriginal peoples, and the risk of noncompensable damage is high. In such cases deep consultation, aimed at finding a satislactory inlerim solution, may be required. While precise requirements will vary with the circumstances, the consultation required at this stage may entail the opportunity to make submissions for consideration, formal participation

Supra note 6 at para. 34.

Haida Nation, supra note 3 at para. 44. 
in the decision-making process, and provision of written reasons to show that Aboriginal concems were considered and to reveal the impact they had on the decision. ${ }^{17}$

From the reasoning stated above. it is difficult to argue that the minimum level of consultation described by McLachlin C.J.C. would interfere with the Board's quasi-judicial function. Consultative activities moving toward the other end of the spectrum, as noted, are more complicated and the potential to interfere with the Board's operation would have to be carefully considered. Intensive consultative activities such as these are therefore more likely to be delegated to project proponents. However, absent the imposition of a fiduciary duty between the Board and Aboriginal peoples, it is plausible to suggest that the Board could maintain its quasi-judicial function while also carrying out most types of consultation. The larger question of the Board's effectiveness in carrying out this consultation and its willingness to do so given existing institutional objectives is the subject of further discussion near the end of this article.

Any revisiting of the Board's policies on consultation would likely be welcomed by Aboriginal peoples who have expressed their dissatisfaction about this issue. In recent years, there has been a growing disconnect between the NEB's policy and the expectations of Aboriginal peoples involved in matters before the NEB. While some Aboriginal peoples have expressed a view that the NEB is ultimately responsible for all consultations prior to the approval of an energy project, the general policy of the NEB has been to reject any consultative duty on its part.

An excellent ongoing case study on the significance of Aboriginal claims for resource development projects under the ambit of the NEB is the Mackenzic Valley pipeline (MVP) proposal. This proposal is presently winding its way through the public regulatory process. A major part of this project, if approved by regulators and commenced by its proponents, is a 1,220 kilometre natural gas pipeline in the Mackenzie Valley. Several First Nations have claims to land along the suggested routc of the pipeline.

In the context of the planning stages of the pipeline project, there is a distinct difference between First Nations which have settled their land claims with the government, and those which have not. The disconnect noted above, between NEB policy on consultation and the expectations of First Nations, is very evident in the case of the First Nations in the latter group, while those in the former group have taken an entirely different approach to the NEB regulatory process and the project itself. These three First Nations with settled land claims. being the Inuvialuit, Gwich 'in, and Sahtu, have actually invested in the pipeline through a venture known as the Aboriginal Pipeline Group (APG). In this capacity they have become proponents of the project in the context of the regulatory process rather than being merely interveners.

In contrast, the process has been different for two groups who have not settled land claims and who are not participating in the APG. The Deh Cho and Dene Tha' were initially excluded from the regulatory process largely because their claims over land in the footprint 
of the proposed pipeline have yet to be officially recognized by the federal government. ${ }^{18}$ Both of these groups introduced litigation as a response to being excluded, with the Deh Cho

- claim being settled out of court and the Dene Tha' claim proceeding to a decision in the Federal Court. ${ }^{19}$

In November, 2006, Justice Phelan of the Federal Court ordered the MVP regulatory process halted to the extent that it affected the claimed treaty or Aboriginal rights of the Dene Tha', even though they may not yet be formally recognized by the federal government. ${ }^{20}$ Justice Phelan further ordered that a remedies hearing take place in order for the parties to speak to the issue of how the Dene Tha' could be consulted before the conclusion of the regulatory process. ${ }^{21}$ Finally, on January 30, 2007, Justice Phelan issued a new order lifting the stay against the regulatory hearings, but restricted the release of a final report on the project subject to his discretion."?

The MVP process noted above, which was temporarily halted by Phelan's initial order, is complicated by the fact that the Board has cooperated in a Joint Review Panel (JRP). This is a coordinated public hearing process designed to minimize duplication between different federal government departments, agencies, and regulatory tribunals. As such, the court challenge by the Dene Tha' is not directed specifically at the NEB policy on consultation, but rather at a broader regulatory process designed specifically for the MVP project. Despite this distinction, the decision in Dene $T h a^{\circ}$ demonstrates that courts are willing to put a halt to regulatory proceedings impacting on $A$ boriginal lands where consultation is deemed to be inadequatc. In light of this decision, a similar finding of the Federal Court regarding the Board's consultation policy would likely be decided in a similar fashion. That is, the regulatory process would be halted until adequate consultation is carried out.

Given that the NEB could face such a challenge to its policy on consultation in the near future, it is important to take a closer look at the institutional and statutory structure of the Board to understand what the consequences of a successful challenge might be. This form of analysis leads to the conclusion that the Board could have difficulties taking on a greater consultative duty. Further, there is also reason to believe that should the courts see fit to characterize the NEB as a facilitator for the purposes of consultation between the Crown, Aboriginal peoples, and private industry. that it will also have difficulty in adjusting to this role.

\section{B. Creation of Statute, Creature of Context}

The NEB has proven in the past to be limited both by its statutory mandate and its relationship with government in its response to the issue of Aboriginal consultation. The reasons for this, as the discussion will demonstrate, have to do with the nature of the NEB

ik Deme Tha First Nation v: Canoda (Mfinister of Envirommen), 2006 FC 1354, [2007] I C.N.L.R. I at paras. $70-74$ [0one $\left.7 h a{ }^{\prime}\right]$.

Ibid.

Ibid.

Ibid.

Dene Tha First Nation v. Canada (Minisfer of Enviromment), (30 January 2007). Ottawa T-867-05 (l.C.T.I).) (Court Order). 
as an independent regulatory tribunal, the historical trajectory of the NEB's relationship with the federal government, and the regulatory paradigm espoused by the Board.

The NEB is an independent regulatory tribunal of the federal government and was created in 1959 through the passage of the National Energy Board Act. ${ }^{23}$ Like other economic regulators in Canada and the United States, the NEB was created in order to depoliticize the process of making vital economic decisions, to ensure that individuals entrusted with making those decisions possessed sufficient expert knowledge, and to replace the "chaos" of market competition with top down burcaucratic control of energy policy. ${ }^{24}$ The Board also took on the function of providing the government of the day with expert advice in making policy decisions and drafting legislation. ${ }^{25}$

In addition to the NEB Act, the Board also has responsibilities under other statutes including the Canada Oil and Gas Operations Act, ${ }^{26}$ the Canadian Environmental Assessment Act, ${ }^{27}$ the Northern Pipeline Act, ${ }^{28}$ and the Canadian Petroleum Resources Act. ${ }^{29}$ Pursuant to these statutes, the Board has both a regulatory and advisory mandate. With regard to the regulatory mandate, the Board is responsible for the "regulation of interprovincial and international natural gas, oil and commodity pipelines, international electric power lines and energy exports," as well as for regulating the "safety, environmental and conservation aspects of energy exploration and development on federal lands in the North and offshore areas where there are no specific accords or agreements with a province or territory." 30

In recent years, the Board has distilled its institutional purpose into a concise mission statement: "The National Energy Board's strategic outcome is to provide Canadians with social and economic benefits through the regulation of specific parts of the Canadian energy industry (oil, gas and electricity)."31

In equally succinct fashion, the Board sets out its statutory and institutional objectives by way of five goals:

1. NEB-regulated facilities and activities are safe and secure, and are perceived to be so.

2. NEB-regulated facilitics are built and operated in a manner that protects the environment and respects the rights of those affected.

$23 \quad$ R.S.C. $1985, \mathrm{c} . \mathrm{N}-7$ [NEB Act]

24 Earle Gray, Forny Years in the Public Interest: A History of the National Energy Board (Toronto: Douglas \& McIntyre, 2000) at 13. Sce generally Charles F. Phillips. The Regulation of Public Urilities: Theory and Practice (Arlington, Va.: Public Utilities Reports. Inc.. 1993) at 127-53.

" Gray, ibid. at 82.

R. R.C. 1985 , c. 0.7 .

" S.C. 1992, c. 37.

2* R.S.C. $1985, \mathrm{c} . \mathrm{N}-26$.

R.S.C. 1985, c. 36 (2d Supp.).

10 NEB, Departmentai Performance Report 2004-2005, online: Treasury Board of Canada Secretariat <www.tbs-sel.gc.ca/dpr-rmr/0506/NEB-ONE/neb-one_e.d=pdis at 1.1 .

" $\quad$ bid. at 1.2.4. 
3. Canadians benefit from efficient infrastructure and markets.

4. The NEB fulfills its mandate with the benefit of effective public engagement.

5. The NEB delivers quality outcomes through innovative leadership and effective processes. $^{32}$

Upon review of these goals it can be said that the NEB, both in practical terms and with respect to the way it communicates its own institutional objectives, functions as more than merely a regulatory tribunal. The advisory and operational functions of the Board, in monitoring and working closely with the private sector, are an important part of its overall mission. ${ }^{33}$

Perhaps unsurprisingly, then, it is noted that the NEB went through a major period of realignment along market principles starting in the 1980s. The corresponding adjustment in the Board's regulatory model and organizational structure, labeled as "The Release of the Market" by one former Board chairman, happened concurrently with major pro-market and deregulatory changes across the public sector after the election of a Progressive Conservative govermment in 1984. ${ }^{34}$ Although the reforms of the 1980 s were motivated to a great extent by the impetus of ideology, ${ }^{35}$ they have since been augmented by shifts in government regulation and regulatory institutions attributed to the phenomenon of globalization. ${ }^{36}$

Although changes in government policy over the years have resulted in an adjustment of the Board's regulatory procedures ${ }^{37}$ and a dilution of its advisory role by overlapping activity in other government departments, ${ }^{38}$ the Board's core powers as an independent tribunal have remained consistent: it is a court of record ${ }^{39}$ and has the powers of a superior court with regard to compelling attendance at hearings, ${ }^{\text {th }}$ the examination of witnesses under oath, "the production and inspection of documents, ${ }^{42}$ and the enforcement of its orders. ${ }^{+3}$ The Board's regulatory decisions and the reasons for them are issued as public documents. ${ }^{44}$ These decisions are based on criteria set out in the $N E B A c t$ and invariably rest on a final determination by the Board of what would be in the "public interest" as perceived by the

12 National Energy Board, Strategic Plan 2007-2010. online: NI:B <www.neb.ge.ca/AboutUs/ strtgcpln2007_2010_c.pdts.

11 Giray, supra note 24 at 82.

14 Gray, ibid. at 87. See also Keith F. Miller, "Energy Regulation and the Role of the Market" (1999) 37 Alta L. Rev. 419.

3 Gray, ibid.

3) See generally H.W. Arthurs, "'Mechanical Arts and Merchandise": Canadian Public Administration in the New Economy" (1997) 42 McGill L.J. 29; Alfred C. Aman. The Democratic Deficit: Taming Globalization Through Law Reform (New York: New York University Press. 2004); and Alfred C. Aman, Administrative Law in a Global Era (lthaca, N.Y.: Comell University Press, 1992). applications was removed at s. $119.03(1)$. Sec dn Act to Amend the Nothiomed Energy Board Act amd to" Repeal Certain Enoctments in Consciguence Thereof, S.C. 1990, c. 7, s. 32.

Gray, supra note 24 at 82.

NEA Act, supra note 30, s. II(1).

Ibid., s. $11(3)$.

lbid.

lbid.

lbid., s. 17.

lbid., s. 15(1). 
members of the tribunal hearing the application. ${ }^{45}$ In this capacity, the Board releases approximately 1000 decisions over the course of a year. ${ }^{46}$

As an institution designed to deflect political conflict from Parliament and defuse the political ramifications associated with these decisions, the Board has been largely successful. Indeed, one need only reflect on the politicized nature of encrgy policy in Canada to understand the motives lor introducing an administrative and quasi-judicial process to ensure that "energy projects of national importance were to be dealt with on their merits." ${ }^{n+7}$ In this regard, the Board has reduced Parliamentary conflict over energy policy, as such conflict tends to intensify harmful nationalist rhetoric and exacerbate regional tensions.

This is not to say that Parliament has always been silent on matters within the jurisdiction of the NEB. Rather, the major energy policy debates since the creation of the Board tend to reinforce its success in minimizing political conflict. Indeed, the most divisive political debates during the Board's fifty year tenure have been the result of overt government intervention into the realm of energy policy rather than being the result of any particular regulatory decision of the Board. ${ }^{48}$

While the above discussion speaks to the Board's success at depoliticizing energy policy at the Parliamentary level, the independent structure of the Board is misleading in the sense that it conceals the influence of the federal Cabinet over energy regulation. As with other ostensibly independent economic regulators in Canada and other jurisdictions, there is an unstated tension between the independence of the Board as a quasi-judicial body in its relationship with the government of the day. This is true both wilh respect to the regulatory powers of the Board in matters involving the federal government and with respect to the Board's extensive administrative operations. For those involved in an application to the Board, the tension is no less significant than that which otherwise exists between the judiciary and the representative branches of Canadian government. ${ }^{.9}$

This being said, it seems counterintuitive on its face to suggest that there is a tension between the independence of the Board and the federal government given the fact that Cabinet has only once used its powers in the $N E B$ ACt to reject a decision of the Board. ${ }^{50}$ In fact, it is argued that this absence of government intrusion precisely identifies the nature of the tension between the two sides. That the NEB has retained at least the appearance of autonomy through 11 different governments and ten Prime Ministers cannot be explained away as mere coincidence. Several of these governments, it must be noted, have had markedly different perspectives on the regulation of private enterprise, energy markets, and

4* Ihid. at 49; Roland Priddle. "Reflections on National linergy Board Regulation 1959-98: From Persuasion to Prescription and on to Partincrship" (1999) 37 Alta L. Rev. 524 at 533.

sy

Kent Roach, The Supreme Court on Trial: Judicial Activism or Democratic Dialogue (Toronto: Irwin 1.aw, 2001): F.L. Morton \& Rainer Knopfl, eds., The Charter Revolution and the Court Party (Peterborough, Ont.: Broadview Press, 2000).

si Priddle. supra note 48 at 528.

Ste, e.g., ibid., ss. 52, 54, 58.35(1), 71(3), and $119.09(1)$.

NEB, "Answers to your Questions." online: NEB <www.neb.ge.ca/AboutUs/AnswerYour Questions_c.pdr at 2. 
the structure of the NEB itself. ${ }^{51}$ One would have expected that if the Board was truly independent there would at least be occasional dissonance between it and the government of the day in the same way as exists between government and the judiciary. ${ }^{52}$

It is argued that the absence of overt conflict between the Board and the federal government over the last 50 years can be explained as a function of the structural relationship between the two entities. As political conflict is deflected and defused at the Parliamentary level, it is folded into a particular statutory context that is designed both to reinforce the independence of the Board and to ensure that the Board remains sufficiently flexible so as to adjust its reaction to shifting political currents in government and wider society. Writing about the context in which independent economic regulators operate $v i s-\hat{a}-1 / i s$ government, Marver Bernstein wrote that "[t]he process of regulation is unavoidably political." ${ }^{\text {s3 }}$ He noted further that:

The determination of regulatory goals does not result incvitably from the logical analysis of ecrain economic facts, nor is it automatically deduced from a set of propositions concerning the nature of the political statc and the proper boundaries of political action in a democratic society.

Bernstein's ideas are especially applicable to the NEB, which by statute makes its decisions according to the public interest. How is the NEB, as an agency of government consisting of appointed - rather than elected - board members, to determine the nature of the public interest? An economic regulator such as the NEB runs the risk of becoming obsolete if it cannot correctly identify the public interest at any given time. Bernstein writes that "[r]egulation must appeal both rationally and emotionally to be effective.... Unless the goals of regulation have a strong emotional appeal and are sustained by a sense of fair play and social purpose, the rational formulation of policies will not be sulficient to maintain public support." Thus, economic regulators usually rely upon a democratically-elected government to set the general policies upon which the specilics of their decisions are based. ${ }^{\text {th }}$

Following from Bernstein's analysis, it is possible to identify the discrete means by which the NEB and the federal government have managed to institute reform without endangering the principle of regulatory independence. Since the Board's creation in 1959, the relationship has been characterized in equal parts by respect for the Board's regulatory decisions on the part of government, internally driven institutional adjustment by the NEB in response to changing trends in government and society." incremental regulatory change initiated by

$\$$

The Mulroney government, for example, dranatically altered the regulatory environment in which the NEB operates and brought about a number of important structural and regulatury changes. Sce (iray, supra note 24 at $87-96$.

5 legal scholars. Sec Peler W. Hogg \& Allison A. Bushell. "The Chorrer Dialogue Between Courts and Lecgislatures (Or Perhaps the Charter of Rights lsn't Such A Bid Thing Afler All)" (1997) 35 Osgonde Hall L.J. 75: Christopher P. Manfredi \& James B. Kelly, "Six Degrees of Dialoguc: ^ Response to llogg and Bushell" (1999) 37 Osgoode Hall L.J. 513; and Michatel Mandel, The Churfer of Rights and the Legalization of Polifics in Camada, rev. ed. (Toronto: Thompsonn Educational Publishing, 1994). Marver H. Bernsteiu, Regulating Business by Independent C'ommission (P'rinceton: P'rincetown Universily Press. (955) at 258.

Ithid.

lbid. at 260.

ibid.

Supra note 30 at 2. 
Cabinet, ${ }^{58}$ and major legislative reform instituted in Parliament by the government of the day. ${ }^{59}$ Internally, the Board has deferred to the democratic legitimacy of the executive branch by refraining from controversial regulatory decisions that might be out of step with the direction of the government, ${ }^{60}$ and by adjusting its administrative and operational functions to better reflect the legislative and executive agenda. ${ }^{61}$

In these respects the Board has proven that while it may derive its regulatory powers and quasi-judicial independence from its creation by statute, its existence on a day-to-day basis is constantly being negotiated in the context of its relationship with the government of the day. The Board does not possess judicial independence analogous to that enjoyed by the courts, and it does not give directions to the federal government. This is a consequence of the Board's historical development and structural position within government. In the event that the courts decide to expand the role of the NEB regarding consultation with Aboriginal peoples, it will have to be considered in the context of any reforms to accommodate that role.

Moreover, the position of the NEB as an economic regulator and its institutional makeup have been altered in the last 25 years, according to trends in the global marketplace and public administration. These changes have generally shifted responsibility from public regulatory bodies such as the NEB to private actors. ${ }^{62}$ Any judicial decision requiring the Board to take on the role of a Crown agency for the purposes of consultation, or having to facilitate with other agencies of the Crown in the course of a regulatory application, would saddle the Board with public responsibilities that it is not, at the present time, prepared for.

\section{THE NORTHERN PIPELINE AND THE NEB}

There was little in the way of official interaction between the NEB and Aboriginal peoples before the 1970s. The emergence of Aboriginal peoples as interveners of note in applications before the Board coincided in the 1970s with the increased legal activism of Aboriginal political organizations and the rise of the environmental movement in Canada. The modern era of Aboriginal involvement with the NEB can be traced to successful efforts during the 1970s to stop the construction of a natural gas pipeline in Canada's North. ${ }^{63}$

One of the most significant regulatory processes during this period was initiated on 21 March 1974 by a proposal from Canadian Artic Gas Ltd. (Arctic Gas) to build a pipeline from Prudhoe Bay in Alaska through Canada via the Mackenzie Valley. ${ }^{64}$ In order to allay growing concerns from the public about the effects of such a project in the North, the federal government also initiated an independent, non-binding review of the socioeconomic and environmental impacts of the pipeline. The latter review and its final report (formally known as the Report of the MacKenzic Valley Pipeline Inquiry but commonly referred to as the

\footnotetext{
(* Miller, supra note 34 at 1.

sa Supra nole 37.

(N) Priddle, supra note 48 at $\$ 43$.

it $\quad$ bid. at $\$ 42$.

n2 Miller, supro note 34 at $\mathbf{4 3 8}$.

6) The history of competing proposals for natural gas development in the North during this period is told by François Bregha in Bob Blair 's Pipeline: The Busine'ss and Politics of Northern Energn Developme'II Projects (Toronto: James Lorimer \& Co., 1979). lbid. at 41.
} 
"Berger Report") was released on 9 May 1977..$^{\circ 9}$ It recommended that there be a ten-year moratorium on construction in order to give the federal government time to settle land claims in the region. ${ }^{66}$

The NEB decision released about two months later, which concurrently assessed a competing application by Foothills Pipelines Ltd. (Foothills) for a pipeline along the Alaska highway and through the Yukon, also found flaws in the Artic Gas project. ${ }^{67}$ The Board rejected the Artic Gas proposal and recommended that the Foothills pipeline be constructed instead. Although the southern phase of the Foothills project, also known as the "Prebuild" has been completed, the more ambitious northern phase has not yet been built due to lower than expected natural gas prices.

While the Board's decision on the Artic Gas proposal gave considerable weight to the socio-economic impact of the project, it is not surprising that the Berger review went further both in terms of resources expended in the consultation process, and in the weight given to concerns raised by the Aboriginal people in the North. Indeed, the mandate of the Berger Report was limited to socio-economic issues and it was well known at the time of Justice Berger's appointment as head of the review that he had considerable interest in. and concern for, the Aboriginal peoples of the North. ${ }^{68}$

Another important difference between the NEB decision and the Berger Report involves the terms and conditions for the construction and operation of the pipeline set out by each report. While the former directs its terms and conditions almost exclusively at the private businesses involved in the application to construct the pipeline, the latter focuses most of its terms and conditions on the federal government. Among the many recommendations in volume two of the Berger Report are the following:

Government social assistance payments must be increased to meet the higher cost of living that pipeline construction will bring."

Planning to accommodate in the school system the increased number of pupils that will result from pipelineinduced growth should start soon and should include forecasts of the numbers and needs of pupils. ${ }^{70}$

The federal government should establish a bid differential and exend it to all northern resident lirms that hid on government contracts or on contracts with private sector projects that require government approval. ${ }^{71}$

s: Thomas R. Berger, Northern Frontier. Northern Homeland: The Report of We Weckenzie Valley" Pipeline Inquiry, vol. I (Ottawa: Supply and Services Canada. 1977) [Berger Repor].

to There were also economic reasons for not building the pipeline. See Priddle, stupra nole 45 at 543.

"7 NEB, Northern Pipelince. Reasons for Decision (June 1977). NF13 Decisions can be obtained lrom the NEB's website, online: NEB <www,neb-one.gc.ca>.

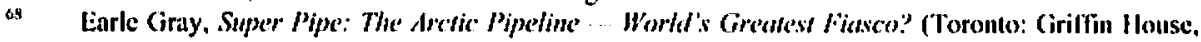
1979) al 177.

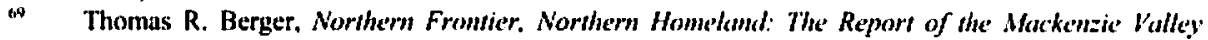
Pipeline Inquin, vol. 2 (Ottawa: Supply and Services Canada, 1977) at 60.

iu $\quad$ thid. at 63.

i1 lbid. at 68. 
The Federal Business Development Bank should be directed to locate and staff one or more regional offices in the Mackenzic Valley and Mackenzic Delta. ${ }^{72}$

There are two explanations for the difference between the NEB decision and the Berger Report in this respect. First, the NEB has traditionally understood its role in terms of responding to applications put before it by private actors. Accordingly, it has usually directed its terms and conditions only at the private partics involved in an application. By contrast, the Berger Report had no such tradition of dealing with private actors. The review was initiated by the federal government and tasked with issuing a report to the Minister of Indian Affairs and Northern Development. ${ }^{73}$ In this way, the review was structured to act as an intermediary between the people of the North and the federal government. Given this role, it seems only fitting that the final Report would make recommendations to the government. The fact that the Report goes beyond this to include a number of terms and conditions directed at the government, which might otherwise be considered outside the purview of an appointed review of this nature, is perhaps a consequence of the wide mandate it was granted and the forceful nature of Justice Berger as chair.

There is also another more subtle reason that explains this difference between the Board's decision and the Berger Report. Namely, that the NEB is not in a practical position to be making public recommendations with regard to government decisions on Aboriginal policy or social policy in general. As explained above, economic regulators gain their legitimacy from democratic government and tend to move along with the ideological and regulatory currents expressed through the electoral system. That the NEB advises the government with regard to technical issues in its field of expertise is not really comparable to any sort of hypothetical role for the NEB as an arbiter of the government's dealings with Aboriginal peoples. Such a role would almost inevitably lead to a much more antagonistic relationship with the government and would potentially politicize an institution that was originally founded to depoliticize the process of energy regulation.

\section{The Duty to Consult}

\section{A. Development of AboriciNal Rights}

The Berger Report turned out to be ahead of its time in its understanding of the potential legal potency of the various claims of Aboriginal peoples in the North. In the 30 years after its release, a combination of aggressive litigation and negotiation has transformed the relationship between First Nations, especially those inhabiting the Canadian hinterland, and all those seeking to exploit natural resources on and under their land.

The Berger Report also turned out to be prescient in its methodology of consultation with northern $A$ boriginal peoples. The courts have only recently set out a standard for consultation that begins to match the approach followed in the Berger review in the 1970s. Indeed, they

Ihid. at 72.

The Berger Report's lerms of reference stated that Justice Berger should "inquire into and report upon the terms and conditions that should be imposed in respect of any right-of-way that might be granted across Crown lands for the purposes of the proposed Mackenzic Valley Pipeline." See lectler from Privy Council of Canada (21 March 1974), ibid. al Appendix 2. P.C. 1974-641. 
now appear to be making up for lost time. In three separate cases in the last two years, the Supreme Court of Canada has turned its attention to the issue of the Crown's duty to consult with Aboriginal peoples. The decisions in Haida Nation ${ }^{74}$ and Taku River ${ }^{75}$ were released on 18 November $2004 .^{76}$ The Court followed up on 24 November 2005 with Mikisew Cree." These decisions continue what is now a long line of cases recognizing and protecting Aboriginal rights and Aboriginal title. More specifically, these threc cases flesh out the duty to consult first introduced in the earlier landmark cases of Sparrow and Delgammokw. ${ }^{7 \times}$ They also extend the significance of the duty to consult by reinforcing a duty to accommodate in certain circumstances.

\section{B. Honour of The Crowy}

It was noted above that the Court in Haida Nation decided that the duty to consult flows from the honour of the Crown and not from the fiduciary relationship with Aboriginal peoples. That view revises a previously accepted lower court interpretation of Delgammukw that the Crown's duty to consult with Aboriginal peoples is triggered only when there is a recognized Aboriginal right or Aboriginal title at issue. "In Haida Nation, the Court makes clear that the duty to consult arises when the Crown has knowledge of the potemial existence of an Aboriginal right or title."

Accordingly, in Haida Nation, McLachlin C.J.C. writes for the Court that the Crown cannot "run roughshod over Aboriginal interests" where there is a serious claim being pursued through negotiation or in the courts. ${ }^{81}$ Rather, when the Crown contemplates conduct that is adverse to the Aboriginal right or title. it must proceed with respect for the possible validity of the claim and map out a consultative process, pending final resolution by negotiation or otherwise. ${ }^{\mathrm{x}}$

\section{SCOPE OF THE DUTY}

Understanding the scope of the duty to consult involves determining what is required in order for the Crown to fulfill that duty in a given circumstance. ${ }^{\mathrm{X} 3}$ In Haida Nation the Court introduces a new variable for the contextual analysis of the Crown's duty to consult: the

is Supra note 3.

3 lbid.

76 The facts of these cases are set out in John M. Olynyk. "The Haida Narion and Taku River Tlingit Decisions: Clarifying Roles and Responsibilitics lor Aboriginal Consultation and Accommodation" (2I February 2005), online: Lawson L.undell L.LP <www.lawsonlundell.condresources/Negotiator article.pdis.

7 Supro note 4. The facts of this case are set out in Brad Amstrong \& Keith Bergner. "Consultation Requirements in the Post-Treaty Context" ( November 2005), online: Lawson Lundell L.I.P < www. lawsonlundell.com/ resources/ConsultationRequirements.pd $>$ at 4.

ix R. 1. Sparrow: [1990] I S.C.R. 1075 at 1119 [Spowrow]; Delgammokw : British Columbics. [1907] 3 S.C.R. 1010 at para. 168 [De/gemmutkin]. Macklem, "From Consultation to Reconciliation: Aboriginal Rights and the (rown's Duty to (onsult" (2000) 79 Can. Bar Rev. 252 at $261-62$. 
relative strength of the Aboriginal right or title in question. This is a new factor in the analysis stemming from the Court's imposition of a duty to consult where the right or title has yet to be formally recognized.

While the Court has expanded the duty to consult to a variety of new situations, it has also been careful not to burden the Crown with an inflexible legal standard for consultation. Indeed, Aboriginal peoples have not been given a general veto over the development of their traditional lands. Rather, the scope of required consultation varies according to the specific circumstances. In this regard, all three recent decisions on consultation ${ }^{84}$ cite an extended passage from Lamer C.J.C. in Delgamuukw:

The nature and scope of the duty of consultation will vary with the circumstances. In occasional cases, when the breach is less serious or relatively minor, it will be no more than a duty to discuss important decisions that will be taken with respect to lands held pursuant to aboriginal title. Of course, even in these rare cases when the minimum acceptable standard is consultation, this consultation must be in good faith, and with the intention of substantially addressing the concerns of the aboriginal peoples whose lands are at issue. In most cases, it will be significantly deeper than mere consultation. Some cases may even require the full consent of an aboriginal nation, particularly when provinces enact hunting and fishing regulations in relation to ahoriginal lands. ${ }^{85}$

Accordingly, the duty to consult varies depending on the strength of the Aboriginal right or title in question and the expected impact of the Crown activity or decision. In situations where the claim is weak or very little impact on the right or title is anticipated, a minimum standard is set out that involves keeping the identified First Nations properly informed and allowing them an opportunity to communicate their concerns to the relevant government agencies. In other situations, the Aboriginal right or title may be recognized by the Crown and the impugned activity may be expected to greatly infringe upon it. In these cases, the Aboriginal group either has to consent to the project or the Sparrow ${ }^{86}$ test for justification of the infringement has to be met.

The vast majority of situations will likely fall between these two extremes. Accordingly, the Court calls for an appropriate degree of accommodation in these cases. As of the present, accommodation is somewhat of an incomplete concept and it is expected that future litigation will at least provide guideposts for government decision-makers in their consultative activities and in the design of consultative procedures. In Haida Nation, the Court makes special note of such procedures and encourages the federal and provincial governments to design regulatory schemes appropriate to "address the procedural requirements appropriate to different problems at different stages." governments are to avoid costly litigation in the future and if the courts' continued principled emphasis on the reconciliation of prior Aboriginal occupation of the land with the reality of Crown sovereignty is to be properly realized.

su Haida Nation, supra note 3 at part. 24; Taku River, supra note 3 at para. 25; and Mikisew Cree, wupra note 4 at para. 61.

s5 Supra nole 78 at para. 168 .

ibid.

$\$ \quad$ Hesida Nation, supra nole 3 at para. 51 
In this regard, one of the most significant outcomes of the Supreme Court's recent trilogy of consultation cases is its demarcation of distinct categories for the assessment of the scope of the Crown's consultative duties. These categories will likely form the basis of any government effort to create administrative policies and procedures in the area of consultation. The Supreme Court has distinguished between situations where the Aboriginal right or title at issue is already recognized, where there is a treaty right at issue as in Mikisew Cree, and where an Aboriginal right or title has not been recognized but the Crown has knowledge of its existence as in Haida Nation and Taku River. In each of these three situations the courts have laid out a basic structure of analysis in order to determine the adequacy of consultation. Although not specifically dealt with by the courts, there is also a fourth category of situation arising where the Aboriginal group in question has successfully negotiated a modern land claims agreement with government. ${ }^{88}$ These agreements tend to be comprehensive in that they set out in detail the mode and limits of government consultation. ${ }^{89}$

\section{The NEB ANd Consultation}

\section{A. The Thref. Policy Phases}

Analysis of the NEB's engagement with Aboriginal peoples since the mid-1970s reveals that its policy has changed over time in reflection of its own institutional priorities and in response to the expansion of Aboriginal rights through the courts. The Board's consultative relationship with Aboriginal peoples can be divided into three phases: the period prior to Hydro-Quebec ${ }^{90}$ in which the concerns of Aboriginal peoples were considered in the analysis of socio-economic impacts; the period after Hydro-Quebec in which the Board shifted responsibility for consultation to the private sector; and the period after the Board issued its MOG on the issue of consultation. While the content of the MOG represents a distinct departure from its previous policy, it is not clear that the Board seriously committed to changing its practices to reflect that fact. An analysis of the Board's practical application of the MOG demonstrates an ambivalence in applying those aspects that differ substantially from its earlier policy.

The Board's initial consideration of Aboriginal concerns, prior to the release of HydroQuebec, was likely the result of its institutional emphasis on the socio-economic impacts of energy development. During this first phase, identification of Aboriginal concerns occurred primarily through its regulatory hearing process in the analysis of socio-economic impacts of proposed projects. There was no specific Aboriginal policy during this time, but rather First Nations were expected to intervene in the general hearing process as public stakeholders. This approach and the growth of the Board's capacity in considering socioeconomic effects has already been discussed in the context of the Northern Pipeline application. Another example of this first phase approach is the 1980 Interprovincial Pipe Line decision regarding the application to build a crude oil pipeline in the North."

This situalion was mentioned in Mikisew Cree, stupra nole 4 at pari. 6

For example, see The Western Aretic Claim Inuvialuit Final Agreement, online: Indian Affairs and Northern Development <www.aine-inac.ge.ca/pr/agr/inu/wesarl_c.pull>.

Supra note 6.

In that decision Aboriginal interveners were unsuccessful in blocking approval of the project. Sec NEB, In the Matter of an Application under the National Energe Board Act of Interprovincial Pipe line (NW) Lid., Reasons for Decision OH-2-80 (March 1981) [Interprovincial Pipe Line]. 
Although the Supreme Court released Sparrow ${ }^{92}$ in 1990, any understanding of the Board's reaction to this decision is hampered by a lack of decisions dealing with Aboriginal issues in the period before Hydro-Quebec was released in 1994. While this makes it difficult to characterize the period as a new phase in the Board's approach, there is reason to believe that the NEB did briefly change its perspective after the release of Sparrow. In Westcoast Energy (1991), the Board interpreted Sparrow as requiring a far more generous approach to Aboriginal consultation. The decision states that

[t]he Board acknowledges that it is bound by the general principle as set out in the Sparrow case that the Crown owes a fiduciary duty to aboriginal peoples to protect and preserve their constilutionatly guaranteed rights. In this case, this refers to the Band's right to hunt, trap and lish on the subject Crown lands as provided in Treaty $8,1899 .^{43}$

Despite acknowledging the Crown's fiduciary duty toward the Prophet River Indian Band and recognizing their Treaty No. $8^{\text {t4 }}$ rights in the area of the pipeline development, the Board found that no infringement of the Band's rights had been made out in the course of the hearings. In this decision the Board applied the Sparrow justification test, for the first and the last time, in assessing a proponent's project application.

The second phase in the Board's consultative history with Aboriginal peoples began after the release of the decision in Hydro-Quebec, where the Supreme Court found that the Board's quasi-judicial function was inconsistent with the imposition of any fiduciary duty." The Court's additional pronouncement on the constitutional responsibility of the Board in regard to s. 35(I) does not appear to have been a significant factor in the regulatory process during this period. Instead, the NEB's policy in this second phase appears to have been based on a calculated strategy to shift all responsibility for consultation onto the private sector. That is, to require that the private actors bringing an application to the Board carry out consultation with Aboriginal peoples and provide evidence of this consultation during the hearing process. ${ }^{46}$ In most cases, this meant that the applicants sought to make a contractual arrangement with the First Nations in question, and government appears to have played little, if any, role in the consultation process. ${ }^{97}$

$92 \quad$ Supra note 78.

93 NEB, In the Malfer of Westcoast Energy Inc., Application dakd 6. Mly 1990, as Amended for the Adself Pipeline Project, Reasons for Decision Gl1-6-90 (June 1991) al 4 [W'esicoast Energy (1991)].

94 Canada, Treaty No. 8.1fade June 21. 1899 and Adhesionts. Reports. Atc. (Otuwa: Qucen's Printer, 1966) [Treaty No. 8].

45 The chronology of this case is interesting in that the Board's original hearing took place a few months before the release of Sparrow and a full year before the Westconst Energy (1991) huarings. The James Bay Cree, who were interveners in the uriginal Hydro-Quebec hearings before the Board, only raised the issue of a fiduciary duty in the subsequent court appeals aller Sparrow had been released.

*6 NEB, In the maner of Trans Canada PipeLines Lid., Applicationdaled 19 December 1995 for a Crossing of the St. Clair River, Reasons for Decision GH-2-96 (May 1996): NEB, In the mather of Trans Canada Pipel.ines I.d. Application dafed 29 April 1998, as amended. for 1999 Facilities, Reasons for Decision (jH-3-98 (November 1998): NEB. In the mather of Maritimes d Northeast Pipelint Management l.t., Sain Jolm Lateral Fucilinies Jpplicution dated 5.Jume 1998, as amended, Reasons for Decision GH-4. 99 (November 1999); NFE, In the multer of Enbridge Pipelines Inc.. Terrace Expansion Program Phase II. Reasons for Decision OH-1-2000 (May 2001); and NLL3, In the matter of Westeoas/ Energy Inc., Grizzly Extension J'ipeline and he Weejoy Lateral, Reasons for Decision GH-2-2002 (November 2002). The NEB has taken on responsibility in the area of "Aboriginal engagement" to ensure that First Nations understand the regulatory process. This program does not provide consultation services: Interview with Chantale Simons, Aboriginal Engagement Specialist at the NEB (28 Febnary 2006). 
The third phase in the Board's consultative relationship with Aboriginal peoples began in March 2002 with the publication of the MOG. Much of the content of the MOG could be characterized as a restatement of the Board's existing policy centered on shifting consultative responsibilities to the privatc sector. However, the MOG represents a significant change because there is an added focus on private sector interaction with government. The MOG states that:

in considering applications before it. the Board will require applicants to elearly identify the Ahoriginal peoples that have an interest in the area of the proposed project and to provide evidence that there has been adequate Crown consultation where rights pursuant to section 35 of the Constinution Act. 1982 may be infringed if the Board approves the applied-for facilities.

In such cases, applicants will be expected to contact the appropriate Crown department or agency wonstre that the requisite Crown consultations are carried ou and to arrange for the inlormation pertaining to those consultations to be filed with the Board. In the absence of such evidence, an application may be considered deficient by the Board or questions may be posed to the applicant to clicit the necessary information."

The MOG effectively devolves responsibility for Crown consultation to the applicants seeking a hearing before the Board. In this way, the Board sets out a policy dictating that it has no independent role in facilitating contact between the Crown and First Nations. Under this policy, applicants before the Board are responsible for providing evidence that First Nations have been informed of the potential implications of the project, that relevant government departments and agencies have been contacted, and that Crown consultation has occurred. Provided that there are no significant outstanding issues between the identified First Nations and the Crown, the Board's 2003 decision in Georgia Strait stands for the principle that regulatory approval may be granted where Crown consultation has been initiated but has not yet been completed.9

The decision in Georgia Strait stands as a high-water mark in terms of the Board's application of the policy set out in the MOG with regard to Crown consultation. The Board utilized several tactics in order to encourage the applicant and both levels of government to initiate and carry out proper consultative processes with the identified First Nations. Over the course of eight months, these tactics included setting clear expectations with the applicant through communications prior to setting the date for a regulatory hearing, delaying the hearing when it was unsatislied with the level of consultation that had taken place, and threatening to cancel the hearings completely if it was not satisfied that adequate consultation would occur. ${ }^{100}$

Despite the Board's relatively aggressive tactics in Georgia Strait, other decisions involving Aboriginal intervenors that were released in 2003 and 2004 reveal a different

** NEB, Letter from the NEI3 to Companies subject to the Jurisdiction of the National Energy Board, Federal and Provincial Ciovemment Departments and Agendas and Representatives of Aboriginal Peoples, "Consultation with A horiginal Peoples"(4 March 2012), online: NliB <https://www.nch.ge.ca/ II-eng/livelink.exe/fetch/2000/90463/231144/142849/Memorandum_Of_Guidance,(AOC8Q3).pdf? nodeid $=142856 \&$ vernum $=0>$ at 3 [emphasis added]. GSX Canada Pipeline Application dated 24 April 2001, Reasons for Decision Gl1-4-2001 (November 2003) [Georgia Siraii]. 
interpretation of the MOG and, in particular, its policy on Crown consultation. ${ }^{101}$ Each of the six decisions released during this period measures the adequacy of consultation entirely on the evidentiary basis of the applicant's private dealings with the intervening groups. The necessity of Crown consultation, while specifically raised as an issue by the Aboriginal intervenors in two of the applications, is not seriously considered by the Board. ${ }^{102}$ Rather, the Board seems to adopt an approach consistent with its second phase policy on consultation despite the changes introduced in the MOG. In this way, the Board focuses on the applicant's consultation with the intervening groups rather than the Crown's consultation activities.

The Board's decision in Sumas 2 is particularly notable for its selective application of the policy set out in the MOG. In this decision, the Board simultaneously relied on the MOG to define the limits of its consultative duties while at the same time ignoring those aspects of the MOG that are incompatible with the second phase approach to consultation. This is a curious outcome, since the MOG is an internally prepared document of the NEB, the contents of which one would expect to be applied in all matters within its regulatory purview.

In contrast to the Board's earlier decision in Georgia Strait, it would appear that the panel members assigned to adjudicate Sumas 2 simply refused to apply the MOG uniformly. Thus, the Board used part of the MOG to reject the Stó:lô Nation's submission with respect to the Board's fiduciary duty: "As noted in the MOG, such a fiduciary role would not be consistent with the Board's statutory role as an independent quasi-judicial tribunal."103 In all other respects, the Board issued its decision as if the MOG had never been released. It ignored the Stó:lô's demand that Crown consultation take place prior to any development, measuring the adequacy of consultation entirely on the basis of the applicant's communications with the intervening First Nations.

Thus, while the Board revoked the MOG in August 2005, it can hardly be stated that it was ever applied with any uniformity, except in the instance of the 2003 Georgia Strait decision. In a letter explaining the reasons behind the revocation of the MOG, the Board states that, "the MOG may not accurately reflect the most recent developments in the law. As a result, the Board has decided to withdraw the MOG at this time for reconsideration and review." ${ }^{104}$ Given the Board's ambivalence about the content of the MOG to begin with, it is not clear what exactly is meant by this statement, or if the Board intends to take action in order to more appropriately align itself with the law in this area.

101 NEB, In the mather of Westcoast Energy Inc.. Southern Mainline Expansion, Reasons for Decision GH1-2002 (January 2003) [Westcoast Energy (2003)]; NFB, In the maller of New Brunswick Power Corp. Application dated 31 May 2001. revised $26 \mathrm{July} \mathrm{2002,} \mathrm{for} \mathrm{an} \mathrm{Imternational} \mathrm{Povier} \mathrm{Line,} \mathrm{Reasons} \mathrm{for}$ Decision EH-2-2002 (May 2003); NEB, In the matter of Trans-Northern Pipelines Inc., Application dated 24 October 20102 for Capacily Expansion and line Reversal Facilities, Rcasons for Decision OHI-2003 (July 2003); NEB, In the matter of EnCana Lkwan Pipeline Inc., Application dated 17 March 2003 for the consiniction and operation of the Ekwan Pipeline, Reasons for Decision GH-1-2003 (September 2003); NEB, In the maller of Trams-Northern Pipelines Inc., Section 58 Application darcal 26 Jume 2003, Reasons for Decision OHW-1-2003 (November 2003): and NE.B, In the matter of Sumas Energy' 2. Inc. Application dated 7 July 1999. amended 23 October 2000. for the consiruction and operation of an Imernational Power line, Reasons for Decision EH-1-2000 (March 2004) [Sumas 2]. Westcoast Energy (2003), ibid; Sumas 2, ibid.

103 Sumas 2, ibid. at 87.

lat Supra note 2 at 2. 
As of writing, there has been no word from the Board on whether or not a new policy will be issued in the future. In the interim, the Board has essentially reverted back to its second phase policy. The current administrative process requires that applicants file evidence prior to the hearing demonstrating that they have identified all of the First Nations likely to be affected by the proposal, and that a strategy for consultation with those groups has been adopted. $^{105}$ The absence of any guidance from the Board on the question of who is responsible for gauging the level of necessary Crown consultation. and giving evidence at the hearing level on the extent of the Crown's consultation, is likely an intended consequence. In this way, the Board's implicit policy as applied in Sumas 2 has become its public policy after the withdrawal of the MOG.

For those familiar with the history of the NEB and its underlying statutory structure, it should not be surprising that the Board prefers the second phase model over the third phase model expressed in the MOG. The second phase approach of shifting responsibility to the private sector has the benefit of working within the Board's regulatory model and institutional objectives while ostensibly satisfying the obligation to ensure that consultations are carried out. The strategy outlined in the MOG of further off-loading the responsibility for Crown consultation to the private sector makes the regulatory process more complicated. Moreover, from the single application of the MOG in Georgia Sirait, it required that private actors act essentially as the Board's proxy in communicating with the federal government. An alternative approach would have the Board communicating its expected standards of consultation directly to the relevant government department and agencies. For reasons related to the Board's history, statutory structure, regulatory model, and institutional objectives, it is unlikely that it would adopt this type of approach voluntarily.

As the case law changes, the Board has instead attempted to change along with it by shifting new responsibilities onto the private sector. Further developments in the case law indicate that the Board is vulnerable on this point. Even though the MOG has never really been followed and has recently been revoked, the Supreme Court ruled in Haida Nation ${ }^{106}$ that only procedural elements of the Crown's duty to consult can be delegated to a third party. Further, the Court stated that "[t]he honour of the Crown cannot be delegated."107 Thus, as the duty to consult has been expanded both in scope and in the varicty of situations that require consultation, the ability of the NEB to delegate that duty has diminished. While the Board's reference to Crown consultation was eliminated along with the MOG, this does not mean that the Board has no duties with respect to ensuring that Crown consultation takes place. The Supreme Count, as far back as Hydro-Quebec, has stated that the Board has an obligation in this regard pursuant to $\mathrm{s} .35$ of Constitution Act. 1982. ${ }^{108}$

\footnotetext{
10s NEB. Leiter from NEB in Companies subject to the Jurisdiction of the National Energy Board, "Infomation to be filed with Applications Where there May be an Aboriginal Interest (3 April 2002). online: NEB <htlps://www,neb.gc.ca/ll-eng/livelink.exe/fetch/2000/90/463/231144/172024/Informa tion_Reyuest_(A0D6S0).pd1'? nodeid $=172025 \&$ vemum=0 $>$.

las Supra note 3.

10\% lbid. at para. 53.

1ai Supra note 8.
} 


\section{B. FUTURE DEVEL.OPMENTS}

There is still a great deal of uncertainty for the NEB in the aftermath of the Supreme Court's trilogy of cases on Aboriginal consultation. The new legal environment has already impacted on the MacKenzie Valley regulatory process. As noted above, that process was partially halted by the Dene Tha' decision in November $2006 .^{109}$ While public hearings of the Joint Review Panel are expected to continue through 2007, the timeline for issuance of a final report has now been pushed into the future and is also subject to the discretion of the Federal Court.

Beyond the impact of Dene Tha' on the timeline and scope of the MVP regulatory hearings, there is a larger question of the influence of the decision more generally on the consultative practices of the NEB. It is my view that Dene Tha' sends a clear message to the Board, and to other regulatory bodies dealing with Aboriginal issues, that they will be held to account for any lailure to consult where there is a potential for the infringement of Aboriginal or treaty rights. That standard applies where a regulatory body is responsible for consultation itself, or if responsibility has been delegated to a project proponent. The Court in Dene Tha' also recognized that in complicated malters there may be many different branches of government involved in a regulatory approval process. Where that is the case, the Crown can be found generally liable for failing to consult with affected First Nations in situations where it is not clear which specific regulatory body has jurisdiction to carry out consultation.

Recently, the Chair of the NEB, Kenneth Vollman, has spoken publicly about the role of regulators in the new era of Aboriginal consultation. ${ }^{16}$ He argued that two points are critical for adapting regulatory processes in this era. First, he suggested that, "Consultation protocols need to be developed as a basis for a common understanding by proponents, aboriginals, government and regulators as to how consultation will be conducted for a project." Vollman also suggested that, "The federal government needs to identify a lead department or agency to deal with Aboriginal concerns with major projects."'I"

With respect to the first point, it is unquestionably important that all the parties involved in the process get together in order to ensure consultation can be carried out smoothly and efficiently. This is something to which the NEB can contribute knowledge and experience, in cooperation with other significant federal and provincial regulatory bodies.

It is the second point which provides some illumination as to the NEB approach to consultation, especially with respect to major projects within its regulatory purview. In his speech Vollman has laid out a wait and see approach in formulating a new consultation strategy for the NEB. This approach assumes that it is the Federal government's obligation to delegate responsibility for consultation and that the NEB will adjust according to public policy decisions. an Armchair Discussion at the 2007 CAMPUT Conference Kelowna, British Columbia, 30 April 2007). online: <www.ncb-onc.gc.ca/newsroom/Speches/2007/rglinnthnw/mtr/rgltnnthnw/mir_c.htm>. 


\title{
Vollman goes on to remark that:
}

\begin{abstract}
Whether the Crown needs to consult separately for NEB applications or whether the Board's process is sulficient to address Aboriginal concerns has not been legally established. In some instances the NEB process may be an effective means for Aboriginal concerns to be addressed; in others, particularly for large projects, there may be a need for a separale Crown consultation process to address broader $A$ boriginal concems. The quasi-judicial process, with its limitations such as an inability to hold discussions one-on-one with an affected party, is not "consultation" in the sense undersloxd by most $A$ horiginal people but its importance in ensuring the mitigation of impacts on Aboriginals cannot be overlooked."
\end{abstract}

Thus, Vollman recognizes the present legal uncertainties regarding the duties of the NEB to consult with Aboriginal peoples. He also suggests a way to deal with these uncertainties without involving the courts. For smaller projects within the Board's regulatory purview, Vollman proposes that the NEB process might be sufficient to deal with Aboriginal concerns. Such a proactive move on the part of the NEB, to take responsibility for the consultation process, could be a productive solution to much of the present uncertainty regarding the duty to consult.

For larger projects, Vollman's experience is that the NEB may be an inappropriate venue. That experience appears to be validated by the public record in recent years. For example, in the JRP process for the Mackenzie Valley pipeline, jurisdictional issues have led to problems in assigning responsibility for consultation with different First Nations. This was made apparent by Justice Phelan in his November ruling in Dene Tha:

Moreover, the quasi-judicial process conducted by the Board may also provide an insufficient forum for First Nations to have their concerns understood and addressed in the contex 1 of large resource development projects. In these instances it may be more appropriate for a separate government agency to carry out consultation. Vollman's suggestion is somewhat inconsistent with McLachlin CJC's remarks in Haida Nation that administrative agencies and impartial decision makers may be tasked with consultation in the most difficult situations. ${ }^{13}$ In my view, the only way to reconcile Vollman's proposal with McLachlin's suggestion in Haida Nation is to recognize that existing regulatory bodies may be unsuited for the task of adjudicating complex consultative scenarios. In these instances, a newly devised administrative agency created by the government seems to be most appropriate.

Along these lines, it is also important to consider the question of whether any new administrative agency would be better at reconciling the concerns of First Nations than the NEB. Given his institution's experience with acting as an intermediary between the Crown, Aboriginal Peoples, and Industry, the Chair of the NEB has clearly identified a problem in achieving workable agreements between these parties within the framework of a quasijudicial model. In devising the appropriate form for an administrative agency that would take responsibility for consultation previously assigned to the NEB, it is important to understand how to avoid problems experienced by the NEB. 
While it is beyond the scope of this article to consider the potential form of any administrative structures that would work alongside the NEB to assist with consultation on larger projects, it is essential to recognize that the role of intermediary in this type of situation is an ongoing one. That is, an agency carrying out consultative functions would be involved in shepherding an ongoing engagement between the Crown, First Nations, and Industry not only through the initial regulatory process before a project is commenced, but also over the implementation phase and after these projects are completed from a business perspective. Further, it is worth considering whether the foundational model for engaging with the parties involved in this tripartite relationship would likely be more successful if the procedures and processes for any new government agency for consultation were based on facilitating negotiation between the different parties involved in these projects rather than the quasi-judicial format. ${ }^{114}$ In my view, Shin Imai makes a persuasive case that negotiation is a more amenable process to the needs and objectives of the consultative project. ${ }^{115}$

\section{Conclusion}

Regardless of what the Federal government decides to do with respect to Aboriginal consultation, this paper has highlighted some problems in this area for the NEB. Even the Board's own Chairman has conceded that consultation represents one of its most significant future challenges. This challenge is best understood with reference to both the historical origin of the Board and its contemporary regulatory mission.

The NEB was created in order to balance the competing demands of Canadians with regard to energy policy by folding political conflict into a quasi-judicial regulatory environment. Its application of technical expertise in the area of energy regulation has served Canada well by minimizing divisive political conflict and managing energy development, without losing sight of the statutory mandate to make its decisions in the public interest. The new challenge for the NEB is adjusting to the reality of Aboriginal consultation within its existing statutory and regulatory framework. For reasons explained in this article, the NEB will likely have difficulties accomplishing this objective regardless of whether it continues to delegate the job to project proponents, or whether it begins to take more responsibility for consultation itself.

Should the courts or the federal government decide to reconsider the role of the NEB in facilitating consultation through its regulatory hearing process, they would be wise to reflect on the practical capability of the NEB to absorb any additional consultation duties. In this article I have shown that the Board's historical development, statutory structure, relationship with the federal government, and regulatory model are all important factors to consider before any decision is made to expand its responsibilities in this area. It would be unwise to make any changes unless the potential for unwanted consequences is limited.

For example, if changes are introduced such that the Board is expected to dictate the extent of required Crown consultation to the federal government, additional changes will

114 For the significance of negotiation to consultation, se Shim Imai, "Sound Science. Careful P'olicy Analysis, and Ongoing Relationships: Inlegrating Litigation and Negotiation in Aboriginal Lands and Resources Disputes" (2003) 41 Osgoode Hall L.J. 587. 
likely be needed in order to make it properly independent from political influence. If the Board is made to be more independent of government, there is then a risk that it could become detached from the democratic process in a way that diminishes its capacity to measure changes in the public interest over time. The Board could also face problems if required to dictate terms of consultation to provincial governments. Given the Board's historical links with the federal government, sensitive issues of federalism and national unity could arise in the event that a provincial government vehemently disagrees with the Board's terms.

Finally, should the courts introduce new adjudicative responsibilities into the Board's regulatory process, it would be important to consider the impact of these responsibilities on the existing regulatory model. It is unlikely that the courts would want to limit the Board's ability to effectively regulate energy markets in the best economic interest of all Canadians. In a globalized economy, the incentive to move investment capital rises as the overall cost of regulatory compliance increases. If the Board is burdened with additional adjudicative responsibilities, particularly in an area outside its traditional expertise, the regulatory process could become far more costly for applicants. Moreover, as Aboriginal peoples are increasingly becoming stakeholders in the development of energy resources on their traditional lands, the flight of investment capital could actually harm their interests more than any changes to the regulatory process would benefit them. 